Jurnal Kesehatan Masyarakat

\title{
The Effectiveness of Circular Hip Massage and Knee Press Massage toward Intensity Change of Labor Pain
}

\author{
Fania Nurul Khoirunnisa ${ }^{3} \bowtie$, Irawati Indrianingrum ${ }^{1}$, Ika Tristanti ${ }^{1}$ \\ ${ }^{1}$ Universitas Muhammadiyah Kudus, Kudus, Indonesia
}

\section{Article Info}

Article History:

Submitted September 2018

Accepted March 2019

Published July 2019

Keywords:

Circular Hip Massage, Knee

Press Massage, labor pain

DOI

https://doi.org/10.15294/

kemas.v15i1.15783

\begin{abstract}
Pain due to labor contraction will cause discomfort therefore pain management is needed to avoid negative effects on both mothers and fetuses. There are some methods in pain management. Pharmacological method has side effects meanwhile non-pharmacological method is more efficient and has minimal side effects. Massage is a non-pharmacological method which may overcome the pain of delivery $(\mathrm{p}<0.05)$. There is an easy method to use and support the delivery assistance for Mother's Day Care, namely Circular Hip and Knee Press Massage. The aim of this study is to know the effectiveness of Circular Hip Massage and Knee Press Massage on the intensity of labor pain with the experimental quasi design. Thr research subjects were 52 pregnant mothers in March to July 2018 at the Maternity Home (RB) and Practice Midwives (BPM) in the Kudus Regency.. Based on the Wilcoxon test, the Circular Hip and Knee Press Massage methods are effective to overcome the pain of delivery $(\mathrm{p}<0.05)$. From Mann-Whitney Test can be concluded that there is a difference in the effectiveness of Circular Hip and Knee Press Massage on the Intensity change of labor Pain. The intensity change of labor Pain with Circular Hip Massage (CHM) is 0.9 , median of 1 (SD 0.445). Meanwhile, the intensity change of labor Pain with Knee Press Massage (KPM) is 0.38, median of 0.5 (SD 0.697). The results of the study are expected to be a reference for the development of scientific health knowledge for mothers and children related to labor pain management.
\end{abstract}

\section{Introduction}

The international community has committed to reducing the Maternal Mortality Rate (MMR). Maternal mortality and morbidity rates are quite high, especially in developing countries. In 2005 the MMR from various countries due to labor problems as much as 536 / 100,000 Life Births (LB). Based on the results of the Indonesian Demographic and Health Survey (IDHS), MMR in Indonesia in 2012 was 359 per $100,000 \mathrm{KH}$. The figure is still quite far from the target of the Sustainable Development Goals (SDG's), which is $70 / 100,000 \mathrm{KH}$ for MMR in 2030 (Kemenkes, 2012, Gamelia et al.,
2016, Mahmudah et al., 2011, Kurniawan et al., 2017, Kurniawan and Maulina, 2015).

It is important to explore various strategies for managing labor pain in order to reduce maternal morbidity. Interventions to reduce pain, anxiety and discomfort during labor are a major part of modern midwifery services that can have an impact on labor. During labor, the body experiences great physical changes to prepare for the birth of the baby and these changes cause pain. Physical, psychological and emotional conditions play a role in the perception of pain experienced by the mother (Susilowati, 2014, Pirdel and Pirdel, 
2009).

Pain during childbirth is oftenly considered different from pain in other clinical condition, with some hypotheses that labor pain is a "good" pain that induces physiological labor, namely the release of natural endorphins. Other evidence shows the side effects of uncontrolled labor pain including hyperventilation which causes respiratory alkalosis and fetal hypoxia, increases the release of catecholamines which cause vasoconstriction of placental vessels and the relationship with increased rates of postpartum depression, opioids easily cross the placenta and affect fetal-neonatal activity and disorders (Byford and Weaver, 2016, Leung et al., 2013).

Labor pain appears as one of the complaints that cause discomfort to the mother. First stage labor pain is caused by uterine contractions and cervical dilation through afferent nerves found in the uterus and cervix leading to dorsal horn spinal cord at the level of thoracic 10 (TH 10) to lumbar 1 (L1). Contractions at the start of labor are usually short and weak, oftenly lasting from mild contractions for a period of 15 to 30 seconds and developing into moderate pain with a length of contraction of 30 to 40 seconds and frequency every 5 to 7 minutes. There is a close relationship between the opening of the cervix with the intensity of pain, the pain sensation is $\pm 15-30$ seconds after the start of contraction. Pain in labor can cause hyperventilation so that the oxygen requirement increases, an increase in blood pressure, reduced intestinal motility and urinary vesica and an increase in catecholamines which cause disruption of uterine contractions so that there can be long term delivery (Wignyomartono, 2012, Fraser DM, 2011, Labor S, 2008, Fatmawati and Arifiani, 2017).

Cortisol and catecholamine hormones are secreted in response to labor pain and anxiety through the mechanism of sympathetic nervous system action. This hormonal imbalance causes disruption in the progress of cervical dilatation, narrowing of the arteries, reduces blood flow carrying oxygen to the uterus, decreases the contraction of the smooth muscle of the uterine wall and then causes extended labor time (Hosseini et al., 2013,
Calik and Komurcu, 2014, Jenkinson et al., 2014, Dolatian et al., 2010).

Physical and emotional factors play a role in receiving labor pain. Various methods have been introduced to women in coping with labor pain, both pharmacologically and non-pharmacologically. Some pharmacological methods include sedatives, analgesia, pudendal, paracervical and epidural anesthesia. Pharmacological pain management is more effective than non-pharmacological methods, but pharmacological methods have adverse side effects for the mother. Some of the side effects that can occur from pharmacological methods including epidurals are numbness or weakness in one or both legs occurring in about 1 in 550 women and potentially life-threatening complications occur in about 1 in 4000 women. Epidural anesthesia can cause a sympathetic blockage and consequently a decrease in maternal cardiac output, distension of the bladder, extension of the second stage of labor. Overall, epidural anesthesia is the gold standard in pharmacological methods. However, the available evidences show that parenteral opioids are even harmful to babies, but are widely used. Nonpharmacological methods are considered more efficient with minimum risks or side effects. Some non-pharmacological methods that can be applied include breathing techniques, labor position setting, massage and hot or cold therapy (Ogboli-Nwasor et al., 2011, Karami et al., 2007).

Massage technique can reduce pain and tension during labor. Excessive anxiety and increased pain perception lead to a stress response, increasing cortisol and adrenaline levels which results in narrowing of the arteries, reducing blood flow that carries oxygen to the uterus and fetus resulting in decreased placental perfusion that affects uterine contractions, resulting in prolonged labor for the occurrence of asphyxiation in BBL. With a massage there will be a decrease in tension, this can result in reduced pain intensity. Massage produces the hormone oxytocin and helps the mother to relax (Yaunin et al., 2010, Calik and Komurcu, 2014, Jenkinson et al., 2014, Dolatian et al., 2010)

Massage is one of the complementary therapies in labor. Research shows the effects 
of massage on connective tissue will result in an increase in beta-endorphins. Massage can reduce adrenaline production and increase the release of oxytocin and endorphins. Endorphins are powerful hormones that provide increased energy, relaxation and pain relief at one time. Massage has a positive effect helping mother to overcome pain and promote positive feelings in the labor process (Dubey S, 2017, BolbolHaghighi et al., 2016).

Of the various massage methods there is an easy method to do even by labor assistants, namely the Circular Hip and Knee Press Massage methods. Circular hip massage is a massage on the hip in a circular motion repeatedly, repetition of this movement in the area of discomfort especially aims to help relieve pain. At the beginning of labor, occasional pain manifests as abdominal pain, pelvic pain and back pain. While the knee press massage method is a push made on the maternal knee with a sitting position when contracting. By putting pressure on the knee, stimulation of peripheral receptors occurs, stimulants reach the brain through the spinal cord, thereby reducing pain perception in maternity (Aziato et al., 2017)Dubey S, 2017)

Research regarding the comparison of the effectiveness of the Circular Hip and Knee Press Massage methods as a medium for decreasing labor pain intensity has never been done. Similar research regarding the effectiveness of massage in labor was carried out by Atun Roudhotul and Suryaningsih (2010) on the effectiveness of counterpressure and endorphin massage techniques for labor pain in maternity, the results of effective massage methods to reduce pain $(\rho$-value $<0.05)$ and techniques were obtained. Counterpressure technique is more effective 2.34 times than endorphin massage (Mảrifah and Surtiningsih, 2010).

Advantages of the Circular Hip and Knee Press Massage Method is easy to do and can support the care of your dear mother. Both methods can be carried out by helpers and families as companions for mothers in labor. Assistance efforts are proven to reduce anxiety in labor ( $\mathrm{p}<0.05)$. In the Circular Hip Massage method massage is performed on the sacral area, where in this area as a center of visceral pain due to pain (nociceptive) arising from mechanical distension of the lower uterine segment and opening of the cervix, repetition of this movement in areas of discomfort primarily aims to help ease the feeling sick. While the knee press massage method works with the pain distraction system through applying pressure to the knee (Dubey S, 2017, Datta, 2010)

Pain reduction management is still a priority in childbirth care as part of maternal and child health promotion. It is hoped that the Circular Hip and Knee Press Massage methods can be a new alternative in the management of labor pain and in order to support efforts to increase the role of the family through childbirth assistance as care for the mother. The research objective is to determine the effectiveness of Circular Hip and Knee Press Massage on the intensity of labor pain.

\section{Method}

The research design was Quasi experimental with 52 subjects giving birth at the Pratama Clinic and Independent Practice Midwife (Bidan Praktek Mandiri/BPM) in the Kudus Regency area that fulfilled the inclusion and exclusion criteria. A total of 26 maternity women received interventions for labor pain management with the Circular Hip Massage technique and as many as 26 others received the Knee Press Massage intervention. The sampling technique is non randomization by consecutive sampling.

The types and sources of data come from primary and secondary data. Secondary data was obtained from medical records of respondents, while primary data collection instruments used a checklist. The checklist is used to assess the implementation of massage and contains data on maternal characteristics, pain measurement using Numerical Rating Scales / NRS.

Before data collection is done, researcher conducts sample selection based on inclusion and exclusion criteria. Data collection starts from the explanation of the researcher to the respondents related to the research, if the respondent agrees, the researcher gives an informed consent to be signed. Next step is the intervention as well as teaching the family about the method of massage performed. Measuring the level of pain is carried out before and after 
the intervention in the active phase, namely the opening of 5-7 cm. Measurements at the opening are based on the pattern of increasing labor pain which begins to peak at the opening of $\geq 5 \mathrm{~cm}$ and at the opening of $>7 \mathrm{~cm}$ the influence of external stimuli is minimumly received by the mother's senses. Assistance and evaluation are carried out during the active phase. After collecting the data, it is continued with tabulation activities for further data analysis.

The univariable analysis design was carried out to describe the characteristics of the research subject. The characteristics described are maternal age, gestational age, parity and mother's education. Bivariate analysis was performed to assess the effectiveness of intervention treatments namely Circular Hip Massage and Knee Press Massage on the intensity of labor pain. Statistical analysis in this study used the Wilcoxon and Mann-Whitney tests.

\section{Result and Discussion}

In the research subject, the data collection of maternal characteristics and the scale of maternal pain were done before and after the intervention. The data obtained were analyzed using the Wilcoxon test and Mann-Whitney differences test to assess the the effectiveness of the two pain management methods studied. The characteristics of the research subjects assessed in this study were age, gestational age, education and parity.

The majority of respondents from both groups were 46 people $(88.5 \%)$ in the $20-35$ year age category. The age group 20-35 years is a category of healthy reproductive age. Mothers at reproductive age have sufficient tolerance for labor pain, this is related to maternal energy, conditions and functions of reproductive organs that have developed optimally and function properly (Siswosudarmo, 2008, Khoirunnisa et al., 2017, Wiknjosastro, 2005).

As many as 50 respondents (96\%)

Table 1. Research Subject Characteristics

\begin{tabular}{|c|c|c|c|c|}
\hline \multirow[t]{2}{*}{ No } & \multirow[t]{2}{*}{ Characteristics } & \multicolumn{2}{|c|}{ Pain Management } & \multirow[t]{2}{*}{$\mathrm{p}$ value } \\
\hline & & $\begin{array}{l}\text { CHM } \\
(n=26)\end{array}$ & $\begin{array}{l}\text { KPM } \\
(\mathrm{n}=26)\end{array}$ & \\
\hline \multirow[t]{4}{*}{1.} & Age (years) & & & $0,139^{\mathrm{a})}$ \\
\hline & $<20$ & 2 & 1 & \\
\hline & $20-35$ & 23 & 23 & \\
\hline & $>35$ & 1 & 2 & \\
\hline \multirow[t]{4}{*}{2.} & Gestational Age & & & \\
\hline & $<37$ & 0 & 1 & $0,139^{a)}$ \\
\hline & $37-41$ & 26 & 24 & \\
\hline & $\geq 42$ & 0 & 1 & \\
\hline \multirow[t]{4}{*}{3.} & Education & & & \\
\hline & Elementary & 8 & 4 & $0,266^{\mathrm{b})}$ \\
\hline & High School & 16 & 17 & \\
\hline & Graduate & 2 & 5 & \\
\hline \multirow[t]{3}{*}{4.} & Parity & & & $0,089^{c)}$ \\
\hline & Primipara & 7 & 14 & \\
\hline & Multipara & 19 & 12 & \\
\hline
\end{tabular}

Source : Primary Data (2018)

Note : a) Kolmogorov-Smirnov Test

b) Chi-Square Test

c) Fisher Exact Test 
were in the proper gestational age category namely 37-41 weeks. Near the time of delivery, normal cervical softening occurs. Softening and stretching of the cervix are related to the perception of pain. Pain in labor is caused by several factors including anoxia in the uterine muscle, contraction of the uterine muscles and the occurrence of stretching of the cervix (Moghadam D.A et al., 2013)

The high school education (junior and senior high school) is the highest level of education of the total respondents as many as 33 persons $(63 \%)$. The education level is associated with pain perception and labor anxiety through the acceptance of knowledge and information that are considered different according to the level of education (Almond., 2005).

Most of the respondents were multipara mothers. In multipara women, the cervix will experience softening before labor, the cervix in the multipara is softer compared to primipara so that there are differences in sensory reception and pain sensitivity. Primipara mothers receive sensory pain more intense than multipara. Primipara mothers show increased anxiety and doubt to anticipate pain during labor. In multipara the perception of pain is also influenced by previous labor experiences (Afritayeni, 2017).

The research subjects were given Circular Hip Massage and Knee Press Massage interventions and then the intensity of pain before and after the intervention was assessed. Comparative analysis of the intensity of labor pain in the intervention of Circular Hip.

The average intensity of labor pain before Circular Hip Massage (CHM) was 7.85 with a median of 8 (SD 1.255), the lowest pain was 6 and the highest was 10 with the estimated 95\% interval believed to be painful before CHM was between $7.34-8.35$. While the average intensity of labor pain after the Circular Hip Massage was 6.88 with a median of 7 (SD 1,306), the lowest pain was 5 and the highest was 10 with the estimated 95\% interval believed to be the intensity of pain after CHM intervention was between 6,36- 7.41. Based on statistical tests, for labor pain before and after CHM intervention showed a significant difference $(\mathrm{p}<0.05)$.

The result is aligned with the hypothesis of Jagdish and Abirami (2016) that the Circular Hip Massage technique is effective for treating labor pain $(p=0.001)$. In the Circular Hip Massage method massage is performed on sacred areas where in this area as a center of visceral pain due to pain stimulation (nociceptive) arising from mechanical distension of the lower uterine segment and opening of the cervix, repetition of this movement in areas of discomfort accompanied by controlled breathing techniques aimed at to help alleviate pain (Lowe, 2002, Jagdish G.S and Abirama, 2016).

Circular Hip Massage is effective in dealing with grievances of lower back pain that is often felt by the mother during the active phase. Tzeng YL and Su TJ, 2008 stated that as many as $75.3 \%$ of mothers had back pain during labor and increased along with the progress of labor. Back pain during pregnancy and childbirth is associated with loosening of the pelvic ligaments caused by the production of the hormone relaxin, a polypeptide produced by the corpus luteum, fluid retention in connective tissue or sacroiliac dysfunction. Changes in the posture of pregnant women to balance the anterior weight cause an increase in lumbar lordosis and increase pressure on the lower back. Changes in bone mass density are also considered to have an etiological role in back pain during pregnancy (Tzeng Y.L, 2008, Keskin et al., 2012).

At the time of labor, the pain impulse is channeled through the T11 - 12 spinal nerve

Table 2 Before and After Circular Hip Massage Labor Pain Intensity Comparation

\begin{tabular}{lllllll}
\hline Variabel & Mean & Median & SD & Min-Max & $95 \%$ CI & P value \\
\hline Pre test & 7,85 & 8 & 1,255 & $6-10$ & $7,34-8,35$ & $0,000^{*}$ \\
Post test & 6,88 & 7 & 1,306 & $5-10$ & $6,36-7,41$ & \\
\hline Source & Prin & &
\end{tabular}

Source : Primary Data (2018)

Note $\left.\quad{ }^{*}\right)$ Wilcoxon Test 
Table 3 Before and After Knee Press Massage Labor Pain Intensity Comparation

\begin{tabular}{lllllll}
\hline Variabel & Mean & Median & SD & Min-Max & $95 \%$ CI & P value \\
\hline Pre test & 7,88 & 8 & 0,952 & $6-10$ & $7,50-8,27$ & $0,012^{*}$ \\
Post test & 7,50 & 7 & 1,105 & $5-10$ & $7,05-7,95$ & \\
\hline
\end{tabular}

Source : Primary Data (2018)

Note $\quad{ }^{\star}$ ) Wilcoxon Test

Table 4 Comparison of Circular Hip Massage and Knee Press Massage Technique Effectiveness on Labor Pain Intensity Change

\begin{tabular}{lllllll}
\hline Pain Mng. & Mean & Median & SD & SE & P value & N \\
\hline CHM & 0,96 & 1 & 0,445 & 0,870 & $0,001^{*}$ & 26 \\
KPM & 0,38 & 0,5 & 0,697 & 0,137 & & 26 \\
\hline
\end{tabular}

Source : Primary Data (2018)

Note $\left.\quad:{ }^{\star}\right)$ Mann-Whitney Test

segment, thorax and upper lumbar through the sympathetic nerve which then opens the gate of pain so that the mother feels pain in the lower back. The impulse from the massage carried out in the lower back area radiates to $\mathrm{A}, \beta, \mathrm{C}$ myelin closes the pain gate and also the release of the hormone $\beta$-endorphin from the interneuron in the spinal cord which closes the pain gate. Thus mothers with Circular Hip Massage experience less pain in the lower lumbar and sacral regions (Devadason J.M, 2010).

The intervention in the second group was done by the Knee Press Massage method. The analysis results showed that the average intensity of labor pain before Knee Press Massage (KPM) was 7.88 with a median of 8 (SD 0.952 ), the lowest pain was 6 and the highest was 10 with the estimated $95 \%$ interval believed to be painful before KPM was between 7.508.27. While the average intensity of labor pain after KPM is 7.50 with a median 7 (SD 1.105), the lowest pain is 5 and the highest is 10 with the estimated 95\% interval believed the pain intensity after the KPM intervention is between 7.05-7, 95. Based on statistical tests, for labor pain before and after the KPM intervention there was a significant difference $(\mathrm{p}<0.05)$.

The knee press massage method is one of the labor pain management that works through the mechanism of pain distraction by giving pressure to the knee. The knee press massage method is a push made on the maternal knee with a sitting position when contracting. By putting pressure on the knee, stimulation occurs in the pelvic cavity between the bladder and rectum at peripheral receptors, stimulants reach the brain through the spinal cord, thereby reducing the perception of pain in the mother (Dubey, 2015; Datta, 2010).

Similar research was conducted by Perlman et al., 2012 who examined massage therapy for knee osteoarthritis. The hypothesis in the research states that the administration of mild pressure and massage including the knee can reduce muscle tension, balance muscle tension in all joints, positive mechanical changes in the muscles, increase joint flexibility and block pain signals.

Thus, the first hypothesis is accepted, namely the effectiveness of Circular Hip Massage and Knee Press Massage on the intensity of labor pain. To answer the second hypothesis, the Mann-Whitney test was carried out by analyzing the comparison of the effectiveness of the technique of Circular Hip Massage and Knee Press Massage on changes in labor pain intensity.

The analysis results showed that the average change in intensity of labor pain in the Circular Hip Massage (CHM) intervention was 0.96 with a median of 1 (SD 0.445). While the average change in labor pain intensity in the Knee Press Massage intervention (KPM) was 0.38 with a median of 0.5 (SD 0.697). Based on statistical tests, changes in the intensity of labor pain in CHM and KPM interventions showed significant differences $(\mathrm{p}<0.05)$.

The Circular Hip Massage and Knee 
Press Massage is a method of managing labor pain that is easy to do, without tools and as one of the efforts to support childbirth assistance (mother's care). Both of these massage methods have their own mechanisms to influence the perception of maternal pain.

The circular hip massage method is to massage the hip in a circular motion repeatedly to help relieve pain and create a relaxing effect. While the knee press massage method is a push made on the maternal knee during contraction by giving pressure to the knee to stimulate peripheral receptors. Through the effects of distraction, the Knee Press Massage is considered to be able to overcome labor pain. Relaxation is a technique for releasing tension, while distraction techniques are a distraction from things that cause pain (Perry and Potter, 2006).

A similar study was conducted by Vindora (2013) who examined the comparison of the effectiveness of distraction and relaxation techniques to changes in pain intensity in hernia post operation patients showed there were differences in the effectiveness of distraction and relaxation techniques for changes in pain intensity ( $p$ value $=0.001)$ (Vindora et al., 2013).

The distraction effect produced by the Knee Press Massage method can reduce pain perception by stimulating the descending control system which results in fewer pain stimulation transmitted to the brain. In the work mechanism of pain management through attempts at distraction, stimulation in the form of a focus of more passive attention with stimulation from the environment or other that attract the attention of the mother to divert the pain. This does not require as much mental concentration as the steps involved in deliberate intervention, but may be less effective when the pain is severe. While the Circular Hip Massage method is able to reduce the intensity of pain through the relaxation effects produced. There is some evidence that relaxation responses activate mechanoreceptors in tissues innervated by alpha beta fibers with subsequent central nervous system (CNS) effects on the pituitary gland, limbic system and other mechanisms. The relaxation effect is able to activate the parasympathetic nervous system with the effect of decreasing heart rate, blood pressure, biochemical levels (including blood and saliva stress levels, endorphins and serotonin), brain activation changes associated with anxiety reduction (Perlman, 2012, Prasertcharoensuk and Thinkhamrop, 2004).

In previous literature and studies it was claimed that subjective experience of pain and brain activation related to pain management is through stimulating a series of functional brain regions including the thalamus, somatosensory cortex, secondary somatosensory cortex, insula, anterior cingulate cortex, prefrontal cortex, and cerebellum. All of these brain regions are known to show activation that is significantly associated with subjective pain experience (Aksoy et al., 2016).

In this research, based on the results of the analysis, the average change in intensity of labor pain in the Circular Hip Massage (CHM) intervention was 0.96 with a median of 1 (SD 0.445). While the average change in labor pain intensity in the Knee Press Massage intervention (KPM) was 0.38 with a median of 0.5 (SD 0.697). Thus it can be concluded that the two methods are effectively used as nonpharmacological methods in the management of labor pain. The average change in pain intensity in the Circular Hip Massage group with a value of 0.96 , was greater than the Knee Press Massage group of 0.5 . In this study, there are limitations to the researchers in controlling related variables, including maternal anxiety levels and previous pain experience. A small sample size was also considered influential and the study subjects in this study were not randomly selected, so the findings in the study could be biased and cannot be generalized to other populations. Cognitive coping strategies such as distraction and relaxation techniques need to be conveyed to the mother of childbirth as part of labor management that can help the mother cope with labor pain (Klomp et al., 2017, Cornally et al., 2014).

\section{Conclussion}

Based on statistical tests, the Circular Hip Massage and Knee Press Massage methods are effective for treating labor pain $(\mathrm{p}<0.05)$. There is a difference in effectiveness between Circular Hip Massage and Knee Press Massage on Changes in Intensity of Labor Pain. The average change in intensity of labor pain in the Circular 
Hip Massage (CHM) intervention was 0.96 with a median of 1 (SD 0.445). While the average change in labor pain intensity in the Knee Press Massage intervention (KPM) was 0.38 with a median of 0.5 (SD 0.697). Further research is needed to assess the determinants of labor pain with different variables or interventions with a larger sample size. The results of the study are expected to be a reference for the scientific development of health promotion for mothers and children related to the management of labor pain.

\section{Reference}

Afritayeni 2017. Hubungan Umur, Paritas dan Pendamping Persalinan dengan Intensitas Nyeri Persalinan Kala I Journal Endurance, 2(2), 178-85.

Aksoy, H., Yücel, B., Aksoy, U., Acmaz, G., Aydin, T. \& Babayigit, M. A. 2016. The relationship between expectation, experience and perception of labour pain: an observational study. SpringerOpen, 2016(5).

Almond., C. J. 2005. Core Curriculum for Professional Education in Pain : Pain and Pregnancy and Labor. IASP Press.

Aziato, L., Acheampong, A. K. \& Umoar, K. L. 2017. Labour pain experiences and perceptions: a qualitative study among post-partum women in Ghana. BMC Pregnancy and Childbirth $17(73)$.

Bolbol-Haghighi, N., Masoumi, S. Z. \& Kazemi, F. 2016. Effect of Massage Therapy on Duration of Labour: A Randomized Controlled Trial. Journal of Clinical and Diagnostic Research, 10(4), 12-15.

Byford, S. \& Weaver, E. 2016. Pain Relief in Labour: How Can We Improve Intrapartum Care? Open Journal of Obstetrics and Gynecology, 2016(6), 785-793.

Calik, K. Y. \& Komurcu, N. 2014. Effects of SP6 Acupuncture Point Stimulation on Labor Pain and Duration of Labor. Iran Red Crescent Med J., 16(10).

Cornally, P., Butler, M., Murphy, M., Rath, A. \& Canty, G. 2014. Exploring women's experiences of care in labour Evidence Based Midwifery, 12(3), 89-94.

Datta, S. 2010. Obstetric Anesthesia Handbook: Nonpharmacological Methods for Relief of Labor Pain.

Devadason J.M, T. G. 2010. A study to assess the effectiveness of circular hip massage on first stage labour pain among primigravida mothers at MBMM hospital, Kerala. . The Tamilnadu Dr. M.G.R. Medical University.
Dolatian, M., Hasanpour, A., Montazeri, S., Heshmat, R. \& Majd, H. A. 2010. The Effect of Reflexology on Pain Intensity and Duration of Labor on Primiparas. Iran Red Crescent Med J.

Dubey S, S. L. 2017. Self-Comforting Techniques and Non-Pharmacologic Methods to Relieve Pain During Labor. International Journal of Science and Research (IJSR), 6(1).

Fatmawati \& Arifiani, F. P. 2017. Efektifitas Masase Efflurage Terhadap Pengurangan Sensasi Rasa Nyeri Persalinan Pada Ibu Primipara. Journal of Issues in Midwifery.

Fraser DM, C. M. 2011. Myles Buku Ajar Bidan, Jakarta, EGC.

Gamelia, E., Masfiah, S. \& Sari, I. P. 2016. The Determinants Of Husband Behavior In The Care Of Pregnant Women. KEMAS, 12(1), 68-75.

Hosseini, E., Asadi, N. \& Zareei, F. 2013. Effect of Massage Therapy on Labor Progress and Plasma Levels of Cortisol in the Active Stage of First Labor. Zahedan Journal of Research in Medical Sciences, 15(9), 35-8.

Jagdish G.S \& Abirama, P. 2016. A Study To Assess The Effectiveness Of Circular Hip Massage On First Stage Labour Pain Among Primi Gravida Mothers At Chrompet Government General Hospital. International Journal of Pharmacy and Biological Sciences, 6(2), 1722.

Jenkinson, B., Josey, N. \& Kruske, S. 2014. BirthSpace: An evidence-based guide to birth environment design. Queensland Centre for Mothers \& Babies: The University of Queensland.

Karami, N. K., Safarzadeh, A. \& Fathizadeh, N. 2007. Effect of Massage Therapy on Severity of Pain and Outcome of Labor in Primipara. Iranian Journal of Nursing and Midwifery Research, 12(1).

Kemenkes 2012. Survei Demografi dan Kesehatan Indonesia. Jakarta.

Keskin, E. A., Onur, O., Keskin, H. L., Gumus, I. I., Kafali, H. \& Turhan, N. 2012. Transcutaneous Electrical Nerve Stimulation Improves Low Back Pain during Pregnancy Gynecol Obstet Invest, 2012(74), 76-83.

Khoirunnisa, F. N., Nasriyah, N. \& Kusumastuti, D. A. 2017. Karakteristik Maternal dan Respon Terhadap Nyeri Persalinan. Indonesia Jurnal Kebidanan, 1(2), 93-99.

Klomp, T., Witteveen, A. B., Jonge, A. D., Hutton, E. K., L., A. \& Lagro-Janssen, M. 2017. A qualitative interview study into experiences of management of labor pain among women 
in midwife-led care in the Netherlands. Journal of Psychosomatic Obstetrics \& Gynecology, 38(2), 94-102.

Kurniawan, A., Sistiarani, C. \& Hariyadi, B. 2017. Early Detection Of High Risk Pregnancy. KEMAS, 12(2).

Kurniawan, H. \& Maulina, M. 2015. Hubungan Antara Usia Ibu dan Paritas dengan Kejadian Plasenta Previa di Rumah Sakit Umum Cut Meutia Kabupaten Aceh Utara Tahun 20122013. Lentera, 15(13).

Labor S, M. S. 2008. The Pain of Labour. BJPsagepub. com, 2(2).

Leung, R. W., LI, J. F., Leung, M. K., Fung, B. K., Fung, L. C., TAI, S., Sing, C. \& Leung, W. 2013. Efficacy of birth ball exercises on labour pain management Hong Kong Med J 19(5).

Lowe, N. K. 2002. The Nature of labor pain. Am J Obstet Gynecol, 186(5), 16-24.

Ma'rifah, A. R. \& Surtiningsih 2010. efektifitas tehnik counter pressure dan endorphin massage terhadap nyeri persalinan kala 1 pada ibu bersalin di RSUD Ajibarang Jurnal Unimus.

Mahmudah, U., Cahyati, W. H. \& Wahyuningsih, A. S. 2011. Faktor Ibu Dan Bayi Yang Berhubungan Dengan Kejadian Kematian Perinatal. KEMAS, 7(1), 41-50.

Moghadam D.A, Delpisheh A, Rezaeian M \& A, K. 2013. Factors Affecting the Labor : A Review Article. . Biomedical \& Pharmacology Journal, 6(2), 161-7.

Ogboli-Nwasor, E., ADAJI, S., BATURE, S. \& SHITTU, O. 2011. Pain relief in labor: A survey of awareness, attitude, and practice of health care providers in Zaria, Nigeria. Journal of Pain Research, 2011(4), 227-232.

Perlman 2012. Massage Therapy for Osteoarthritis of the Knee: A Randomized Dose-Finding
Trial. . PLoS ONE, 7(2).

Pirdel, M. \& PIRDEL, L. 2009. Perceived Environmental Stressor and Pain Perception During Labor Among Primiparous and Multiparous Women. J Reprod Infertil, 10(3). Prasertcharoensuk, W. \& Thinkhamrop, J. 2004. Non-Pharmacologic Labour Pain Relief. $J$ Med Assoc Thai, 87(3), S203-6.

Siswosudarmo, R. 2008. Obstetri Fisiologi, Yogyakarta, Pustaka Cendekia.

Susilowati, E. 2014. Upaya Menciptakan Kenyamanan pada Ibu Bersalinan melalui Setting tempat persalinan. Proceeding Book Workshop Nasional Magister Kebidanan Fakultas Kedokteran Universitas Padjajaran Bandung, 1.

Tzeng Y.L, E. A. 2008. Low back pain during labour and related factors. . Journal of Nursing Research, 16 (3): 231-41, 16(3), 231-41.

Vindora, M., AYU, S. A. \& PRIBADI, T. 2013. Perbandingan efektivitas tehnik distraksi dan relaksasi terhadap perubahan intensitas nyeri pasien post operasi hernia di Menggala tahun 2013 Jurnal Kesehatan Holistik, 8(3), 153-8.

Wignyomartono, S. 2012. Akupuntur untuk Persalinan Bebas Nyeri, Surakarta, UNS Press.

Wiknjosastro, H. 2005. Fisiologi dan Mekanisme Persalinan Normal dalam Ilmu Kebidanan, Jakarta, Yayasan Bina Pustaka Sarwono Prawiroharjo.

Yaunin, Y., ARDI, E. G., LASMINI, P. S. \& ERKADIUS 2010. Hubungan distres dan kadar kortisol dengan kejadian oligoamenorea pada narapidana di lembaga pemasyarakatan wanita se sumatera barat. Majalah Kedokteran Andalas 34(2). 